University of Vermont

UVM ScholarWorks

College of Arts and Sciences Faculty

Publications

College of Arts and Sciences

$8-1-2010$

\title{
Temporal and spatial monitoring of mobile nanoparticles in a vineyard soil: Evidence of nanoaggregate formation
}

\section{N. Perdrial}

Centre de Géochimie de la Surface UMR 7517

\section{J. N. Perdrial}

Centre de Géochimie de la Surface UMR 7517

\section{J. E. Delphin}

Centre de Recherche Grand Est-Colmar

\section{F. Elsass}

Centre de recherche Île-de-France-Versailles - Grignon

N. Liewig

Université de Strasbourg

Follow this and additional works at: https://scholarworks.uvm.edu/casfac

Part of the Agriculture Commons, Climate Commons, and the Sustainability Commons

\section{Recommended Citation}

Perdrial N, Perdrial JN, Delphin JE, Elsass F, Liewig N. Temporal and spatial monitoring of mobile nanoparticles in a vineyard soil: evidence of nanoaggregate formation. European journal of soil science. 2010 Aug;61(4):456-68.

This Article is brought to you for free and open access by the College of Arts and Sciences at UVM ScholarWorks. It has been accepted for inclusion in College of Arts and Sciences Faculty Publications by an authorized administrator of UVM ScholarWorks. For more information, please contact scholarworks@uvm.edu. 


\title{
Temporal and spatial monitoring of mobile nanoparticles in a vineyard soil: evidence of nanoaggregate formation
}

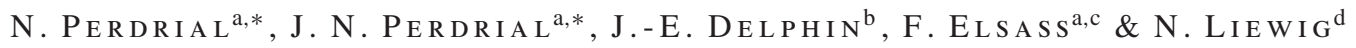 \\ ${ }^{\mathrm{a}}$ Centre de Géochimie de la Surface, UMR-7517 CNRS \& Université Louis Pasteur, Strasbourg, France, ${ }^{\mathrm{b}}$ Equipe Agriculture Durable, \\ UMR-1121 INPL(ENSAIA)-INRA Agronomie et Environnement Nancy-Colmar, INRA Colmar, Nancy, France, ${ }^{\mathrm{c}}$ PESSAC, INRA, \\ Versailles, France and ${ }^{\mathrm{d} I P H C}$, Ecologie Physiologie Ethologie, UMR-7178 CNRS \& Université Louis Pasteur, Strasbourg, France
}

\begin{abstract}
Summary
Mechanisms of formation, stabilization, liberation, transport and deposition of nanoparticles and their relationship to contaminant transport remain scarcely investigated in natural porous media. This study investigated nanoparticles mobilized in the pore space of a French vineyard soil by observing mobile soilderived organic matter (SOM) and minerals in pore fluids over an 8-month monitoring period. Samples were collected in situ and investigated by transmission electron microscopy coupled to electron-dispersive spectroscopy. The main types of nanoparticles transported within the soil were clay, bacteria, SOM and nanoaggregates. Nanometric clay particles were enriched in various metals $(\mathrm{Fe}, \mathrm{Zn}, \mathrm{As}$ and $\mathrm{Pb}$ ) and organicallyderived constituents. Analyses of bacteria showed enrichments in $\mathrm{Pb}$. SOM consisted of small carbon-based particles $(<200 \mathrm{~nm})$ with slight enrichments in various metals. The fourth dominant particle type consisted of the association of particles forming organo-mineral nanoaggregates. Based on the study of more than 22500 individual particles, we propose a schematic interpretation of the evolution of the distribution of particles with depth in a soil profile. The increase of nanoaggregates with depth in the soil seemed to be largely controlled by the ionic strength of soil water and soil hydrodynamics. Seasonal variations in temperature also appear to affect nanoaggregation. Based on the architecture of the nanoaggregates, we propose an improvement of pre-existing models of microaggregation by focusing on early aggregation stages suggesting the importance of bacteria and electrostatic interactions. The process of nanoaggregation can enhance the net reactivity of soil with respect to transported suspended matter, including heavy metals, and can initiate the process of $\mathrm{C}$ sequestration.
\end{abstract}

\section{Introduction}

The fate of nanoparticles and colloids in soils is a topic of intense and continuous research in the field of environmental science. Given their very complex nature because of their very small size and the fact that they can be either of organic or inorganic nature, nanoparticles play a major role in two major environmental issues that are commonly and increasingly being addressed: (i) the fate of carbon (C) with respect to the soil's capacity for $\mathrm{C}$ sequestration and (ii) the transfer of contaminants (especially radionuclides and heavy metals).

Soil constitutes the most important pool of organic C on Earth's surface, at double the size of the atmospheric pool (Schlesinger, 1996). Understanding the fate of $C$ at this functional interface is of major interest as the possible sequestration and preservation of $\mathrm{C}$ in the soil would significantly contribute to the removal

*Present address: Department of Soil, Water and Environmental Science, University of Arizona, Tucson, AZ, 85721-0038, USA.

Correspondence: Nicolas Perdrial. E-mail: perdrial@email.arizona.edu Received 28 September 2009; revised version accepted 20 April 2010 of the greenhouse gas $\mathrm{CO}_{2}$ from the atmosphere (Schlesinger \& Lichter, 2001). As a result, $\mathrm{C}$ sequestration in soils is considered to be a potential mechanism for counteracting the process of global warming (Lal et al., 1998). Several studies show that most of the organic carbon is stabilized for thousands of years in the form of more recalcitrant organo-mineral microaggregates (Six et al., 2000, 2002; Guggenberger \& Kaiser, 2003).

The role of colloids and nanoparticles as pollutant vectors for heavy metal contamination of soil and water has been much emphasized (McDowell-Boyer et al., 1986; McCarthy \& Zachara, 1989; Gueguen \& Dominik, 2003). Sparks (2005) showed that nano- and microscale particles play a considerable role in controlling the life cycle of toxic metals in the environment, whereas Hochella \& Madden (2005) noted the large impact of the combination of small size and large specific surface areas of nanoparticles on geochemical reactions. In the following, understanding interactions between the different types of particles, and particularly organic compounds and minerals, has gained increasing interest. It was proposed that dissolved organic matter stabilizes mineral colloids, leading to an enhanced trace element transport 
in soil solution (Pokrovsky et al., 2005). Organic matter has a large complexation capacity for metals and is readily sorbed onto clay mineral or (oxy)hydroxide surfaces (Baham \& Sposito, 1994; Chenu \& Stotzky, 2002; Kaiser \& Guggenberger, 2003), which increases the probability of the formation of reactive aggregates.

Recently, possible mechanisms involved in the formation of microaggregates (diameter ranging between 20 and $250 \mu \mathrm{m}$ ) have been addressed, and two theories have been proposed: (i) organomineral microaggregates form because organic matter binds to mineral surfaces (Guggenberger \& Kaiser, 2003; Lehmann et al., 2007) and (ii) organo-mineral microaggregates form when minerals surround organic debris (Tisdall \& Oades, 1982; Golchin et al., 1994; Six et al., 2000). These two antithetic possibilities are applied in an attempt to determine possible stages in the formation of microaggregates $(20-250 \mu \mathrm{m})$; however, the determination of factors involved is difficult because of the advanced stage of aggregation. By investigating aggregates formed of nanometric individual particles (operationally defined as nanoaggregates, $<5 \mu \mathrm{m}$ in diameter) we can characterize the early stages of their formation and propose a model for their nucleation as an extension of existing models. We believe that the nanoaggregates that we sampled mark the initial step in constructing larger units, especially those referred to as microaggregates $(<250 \mu \mathrm{m})$.

Recent review papers focusing on the role of colloids and nanoparticles in surface water and soil systems highlight the need to advance knowledge on the mechanisms of formation, stabilization, liberation, transport and deposition of nanoparticles in heterogeneous media; they also emphasize the need for direct investigations in the natural media (McCarthy \& McKay, 2004; Kretzschmar \& Schäfer, 2005; Sen \& Khilar, 2006).

In order to take the complexity of nanoparticles in soils into account it is necessary to look at their general association in the soil system by investigating both organic and inorganic particles and their interaction using appropriate techniques. This paper presents the results of a combination of an 8-month in situ sampling and TEM-based monitoring of characteristics, distribution and evolution of suspended matter (SM) in a temperate climate vineyard soil located in France. The primary objective of the study was to characterize the nature and the role of minimally disturbed SM in a subsurface environment in the context of contaminant transfer. Hypotheses were that the type of SM, and their interactions and environmental characteristics are fundamental factors influencing the contaminant transfer. Results are discussed with respect to their implications for particle interactions and contaminant transfer in the vadose zone.

\section{Materials and methods}

\section{Experimental soil}

The sampled site is an experimental vineyard owned by the Institut National de la Recherche Agronomique (INRA) of Colmar (latitude, $48^{\prime \prime} 4^{\prime} \mathrm{N}$; longitude, $7^{\prime \prime} 16^{\prime} \mathrm{E}$ ) dedicated to the study of the impact of pesticides and herbicides on the overall vineyard environment. Located in the foothills of the Vosges Mountains, the soil is a brown sandy soil (Party et al., 1999) described as a colluviosol and equivalent to a cambisol (FAO/ISRIC/ISSS, 1998) composed of $11 \%$ clay $(<2 \mu \mathrm{m}), 26 \%$ silt $(2-50 \mu \mathrm{m})$ and $63 \%$ sand $(50-2000 \mu \mathrm{m})$. Organic $\mathrm{C}\left(\mathrm{C}_{\mathrm{org}}\right)$ contents of the soil were $17.0 \mathrm{~g} \mathrm{~kg}^{-1}$ for the $0-5 \mathrm{~cm}$ layer, $7.0 \mathrm{~g} \mathrm{~kg}^{-1}$ for the 5-25 cm layer, $5.0 \mathrm{~g} \mathrm{~kg}^{-1}$ for the 25-45 $\mathrm{cm}$ layer and $3.7 \mathrm{~g} \mathrm{~kg}^{-1}$ for the $45-65 \mathrm{~cm}$ layer. The $\mathrm{pH}$ of the soil was rather stable, with layer-dependent values of $7.0(0-5 \mathrm{~cm}), 6.7(5-25 \mathrm{~cm}), 6.6$ $(25-45 \mathrm{~cm})$ and $7.6(45-65 \mathrm{~cm}$, enriched in calcite). The site is surrounded by suburban land use, and it is close to a small city (30 000 inhabitants) located in the Rhine valley, one of the most industrialized areas of Western Europe.

\section{In-situ sampling device}

Particles from soil infiltration water for TEM-EDX analysis were collected with the microlysimeter device described in Perdrial et al. (2008a). This device is based on in situ filtration of soil water and direct collection of particles on a TEM grid. It is especially designed for the in situ sampling of all types of small size SM with a minimal risk of contamination and alteration of their physical properties.

The basic principle of the field device consists of real-time filtration of percolating water by lysimetry. The particle collector consists of TEM grids inserted into a sand bed where the particles are intercepted and gravitationally deposited (Figure 1a). The soil solution collected at the upper stage of the cell is filtered through the 5 - $\mu \mathrm{m}$ cellulose membrane, which allows all particles from nanoparticles to $<5 \mu \mathrm{m}$ to be collected on the underlying grids. After recovery, the grid is rinsed, air-dried and ready for direct investigation of the SM deposit by TEM/EDX without staining. To monitor the nature and the dynamic of the whole pool of nanoparticles in the soil, we introduced the microlysimeter at the bottom of removable PVC columns (Figure 1b). We performed the sampling during an 8-month monitoring campaign (from December 2003 to July 2004) at three different depths (15, 35 and $55 \mathrm{~cm}$ ). Because of analytical problems (poor TEM grid quality leading to $\mathrm{Cu}$ contamination of the samples), the results for February and May (all depths) and April at $15 \mathrm{~cm}$ are not available. Samples were collected and analysed each month. At each depth, a single sampling device containing two grids was inserted. The two grids (one $\mathrm{Cu}$, one $\mathrm{Ti}$ ) permitted verification of the representativeness of the sampling at a centimetre scale, and minimized potential interference between emission rays of the chemical elements during analysis. Above the centimeter scale no precise study of the representativeness had been carried out on that particular site; however, unpublished data using the same device under maize showed no major discrepancies in the lateral representativeness of four different samplings at the same depth.

\section{Particle analysis}

Samples were examined with a high-resolution Philips STEM 420 (FEI Company, Eindhoven, the Netherlands) transmission electron microscope (TEM) at an acceleration voltage of $120 \mathrm{kV}$, coupled 


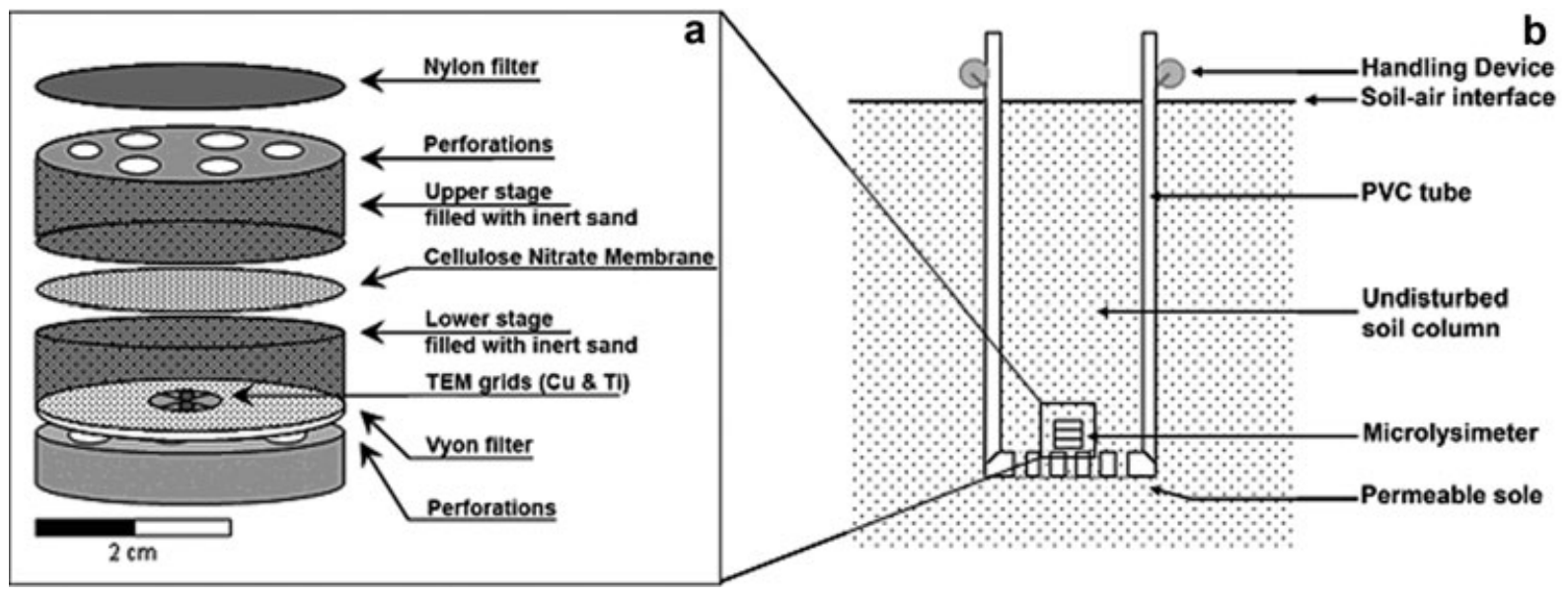

Figure 1 Description of the sampling device: (a) construction of the microlysimeter, (b) cross-section of the field installation (after Perdrial et al., 2008a).

to a microanalysis EDX system (INCA, Oxford Instruments, Abingdon, UK). X-ray fluorescent radiations were recorded between 0 and $20 \mathrm{keV}$ with a $\mathrm{Si} / \mathrm{Li}$ detector and an Atmospheric Thin Window (ATW), allowing the detection of light elements above carbon. The following adaptations of analytical conditions were conducted in order to take the brittleness of very fine particles into account (Elsass, 2006; Elsass et al., 2008) and to limit irradiation damage under the electron beam, particularly in the case of fragile matrices such as clay and organic matter. First, in transmission mode, the size of the incident beam was fitted to the diameter of the analysed particles but not reduced below $100 \mathrm{~nm}$. Second, counting time as well as intensity of the incident beam was reduced ( $30 \mathrm{~s}$ ) in order to optimize the detection of trace elements (signal-to-noise ratio) as beams of strong intensity accelerate mass loss by irradiation damage. It is important to note that, despite all the precautions taken, salt, organic matter and hydroxylated components may undergo irradiation damage. Because of the insensitivity of the method with respect to $\mathrm{H}, \mathrm{OH}$ and $\mathrm{H}_{2} \mathrm{O}$, the thin film factor-based calculated chemical data are 'semi-quantitative'.

The following four-step analytical protocol was applied to each grid. First, on the basis of a general view of the mesh grid, three squares were chosen at random. Second, 25-30 images were obtained from each grid mesh at a magnification of $13500 \times$ covering the entire surface of the square. Third, EDX microanalyses were performed on approximately 30 individual particles representing the distribution of the different types of particles of the square. Finally, each image was processed and analysed with the ImageJ software (Rasband, 1997-2009). The coupling between chemical composition, morphological characteristics and electron optical properties of the particles was then used for a typological study of the particles. Following this sampling method, 16 grids, corresponding to 22766 individual particles were counted and characterized with respect to physical properties such as diameter, perimeter, shape and electron density.

\section{Results and discussion}

\section{Physico-chemical characterization of SM}

The typological characterization performed on the particles present in soil infiltration water of the sampling site highlights eight different types of particles with a diameter $<5 \mu \mathrm{m}$ that were always present in the samples. These types include inorganic particles, particularly euhedral clay particles, anhedral weathered clay particles, oxi-hydroxides and salts. The organic particles included bacteria, soil-derived organic matter (SOM) and organo-mineral aggregates. There were also some undetermined particles.

The cumulative distribution of the particle types during the entire monitoring period (Figure 2) showed that the main types were clay, bacteria (and SOM) and nanoaggregates, representing, respectively, 30, 13 (and 9) and 23\% of the covered area on the grids. This representation was based on particle area, and was chosen to account for the interfacial reactivity of the particles.

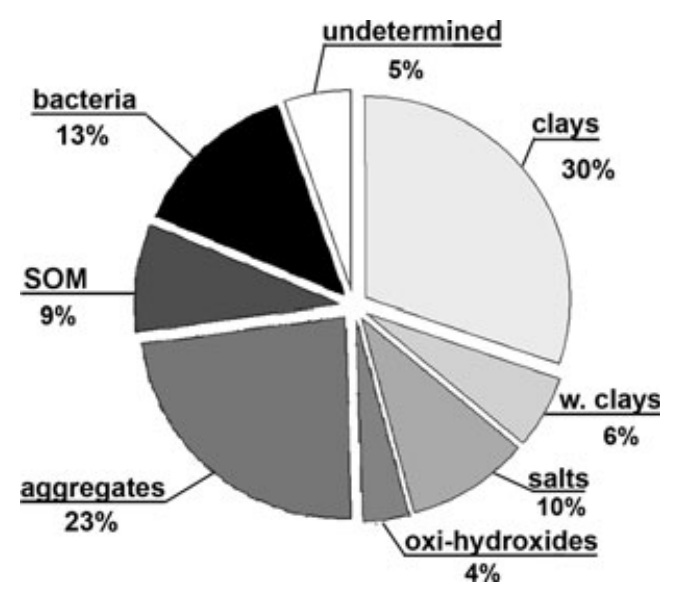

Figure 2 Cumulative average distribution of all types of nanoparticles sampled over an 8-month monitoring period. 
Clays

Clay particles sampled in the soil infiltration water were of small sizes, with more than 81\% (from 1919 measurements) having a diameter of $<0.45 \mu \mathrm{m}$ (Figure $3 \mathrm{a}$ ). The microchemical characterization of the clays shows that their composition ranged between clays containing only tetrahedral (Si4) and octahedral (R3) cations, typical of kaolinite, and clays containing $30 \%$ of interlayer cations $(\mathrm{M}+)$, being typical of mixed-layered illitesmectite (Figure $3 \mathrm{~b}$ ). For comparison, the composition of selected reference clay minerals of the Clay Mineral Society is included in Figure 3(b) (kaolinite KGa-1, illite IMt-1, illite-smectite ISMt-2 and montmorillonite SWy-1). This assemblage reflects the main clay mineral constituents of this soil, indicating that clay particles flowing in the soil pore space have a local source.

Figure 3(c) represents the elemental concentrations of the analysed clay particles normalized to reference clay minerals. Reference clay minerals are the kaolinites $\mathrm{KGa}-1$ and $\mathrm{KGa}-2$, the illites IMt-1 and M8, the illite-smectite ISMt-2 and the montmorillonite SWy-1. With the exception of the illite M8 (Srodon et al., 1986), all reference clays are from the Clay Minerals Society. Elemental contents are expressed in numbers of ions calculated on the basis of the structural formula. The line $\mathrm{y}=1$ corresponds to a mineral composition with a structural formula identical to the one of the corresponding reference mineral. A value y $>1$ (positive anomaly) represents an enrichment, whereas a value $\mathrm{y}<1$ (negative anomaly) represents a depletion, with respect to the reference material. However, according to the structure of clays, the balance between positive and negative anomalies can, in some cases, reflect substitutions. Therefore, the recurrent positive anomalies for the mixed-layered clays reflect the chemical composition of the primary minerals such as Fe-Mg-rich minerals (biotite, chlorite) with more Fe and $\mathrm{Mg}$ in the octahedral site than the reference clay. The calculation of the structural formula consists of first saturating the tetrahedral sites with $\mathrm{Si}$ then $\mathrm{Al}$, then saturating the octahedral site with $\mathrm{Al}, \mathrm{Mg}$ and then $\mathrm{Fe}$ in that sequence. Because the negative

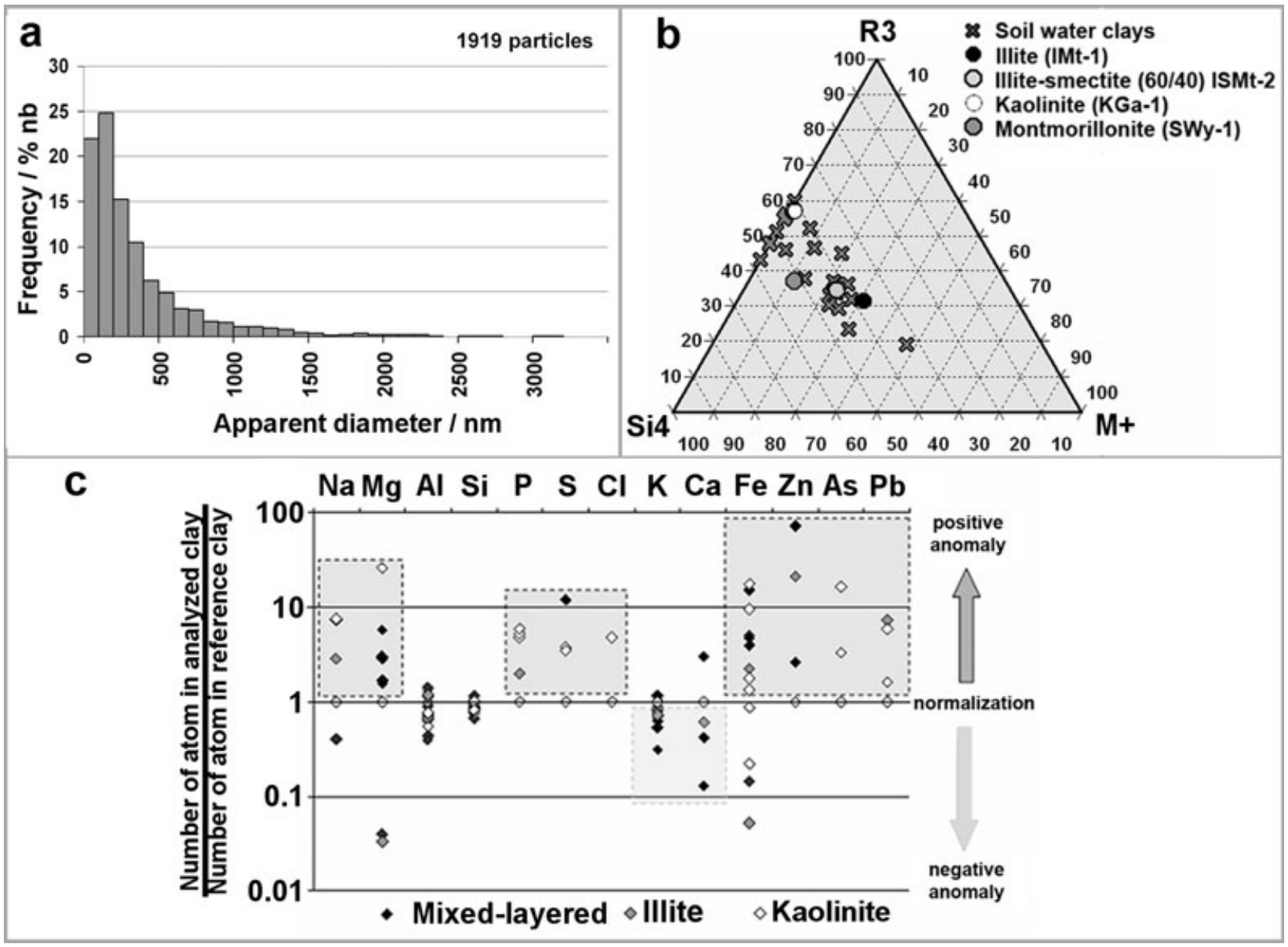

Figure 3 Physical and chemical characteristics of clay particles. (a) Particle size distribution of 1919 clay particles \% nb stands for percent of the number of particles. (b) Ternary plot representation of the chemical analyses performed on clay particles. The number of cations is based on the calculation of the structural formula; crosses represent the analyses from the present study and circles represent reference clay. (c) Normalized elementary concentrations of clay particles representing the ratio between the number of cations based on the structural formula and the reference material. 
anomalies in $\mathrm{Al}$ have a much lower intensity than the $\mathrm{Fe}$ and $\mathrm{Mg}$ positive anomalies, it is probable that a non-negligible part of the Fe constitutes Fe-rich coatings at the surface of clay particles as previously described (Nachtegaal \& Sparks, 2004). Chemical analyses of the clays always show enrichments in three groups of elements: $\mathrm{Na}$ and $\mathrm{Mg} ; \mathrm{S}, \mathrm{P}$ and $\mathrm{Cl}$; and $\mathrm{Fe}, \mathrm{Zn}, \mathrm{As}$ and $\mathrm{Pb}$ (Figure 3c). Enrichments of $\mathrm{Na}$ and $\mathrm{Mg}$ reflect differences in the type of interlayer cations between the reference mineral and that analysed in this study. According to van Oort et al. (2006), we suggest that $\mathrm{Pb}$ was accumulated into Fe coatings, and $\mathrm{Zn}$ was associated with negatively charged constituents of clay-iron coatings. Positive anomalies in $\mathrm{S}, \mathrm{P}$ and $\mathrm{Cl}$ contents reflecting the presence of organic matter $(\mathrm{OM})$ can be explained by two factors: (i) the presence of $\mathrm{OM}$-clay assemblages and (ii) complexes of salts $(\mathrm{Cl})$ with $\mathrm{OM}(\mathrm{S}, \mathrm{P})$ on the frayed-edge sites of phyllosilicates (Auboiroux et al., 1996). These two factors are certainly interdependent, as the tension force induced by the salinity of the soil solution may strongly increase the complexation potential of OM onto clay minerals (Majzik \& Tombacz, 2007).

\section{Bacteria}

Different types of bacteria were sampled in the soil infiltration water (Figure 4), exhibiting different morphological features on the same sample and/or on different grids. Most were bacillus-shaped (Figure $4 \mathrm{a}-\mathrm{c}$ ) and some possessed a flagellum (Figure 4d,c). Micro-colonies of less than 10 cells were episodically observed on the sample grids. The average size of the cells, expressed as circular equivalent, was $0.9 \mu \mathrm{m}$. The intracellular grains, visible in Figure 4(a-c), were enriched in $\mathrm{P}$ and $\mathrm{Pb}$ (Figure $4 \mathrm{~d}$ ) and were previously described and discussed in Perdrial et al. (2008b). Independent of the morpho-type, $40 \%$ of the analysed bacteria contained such enrichments.

\section{Soil-derived organic matter}

Soil-derived organic matter (SOM) was an abundant component in the pool of sampled nanoparticles and was differentiated from the OM connected to bacteria (exopolysacharrides, EPS). Selected,

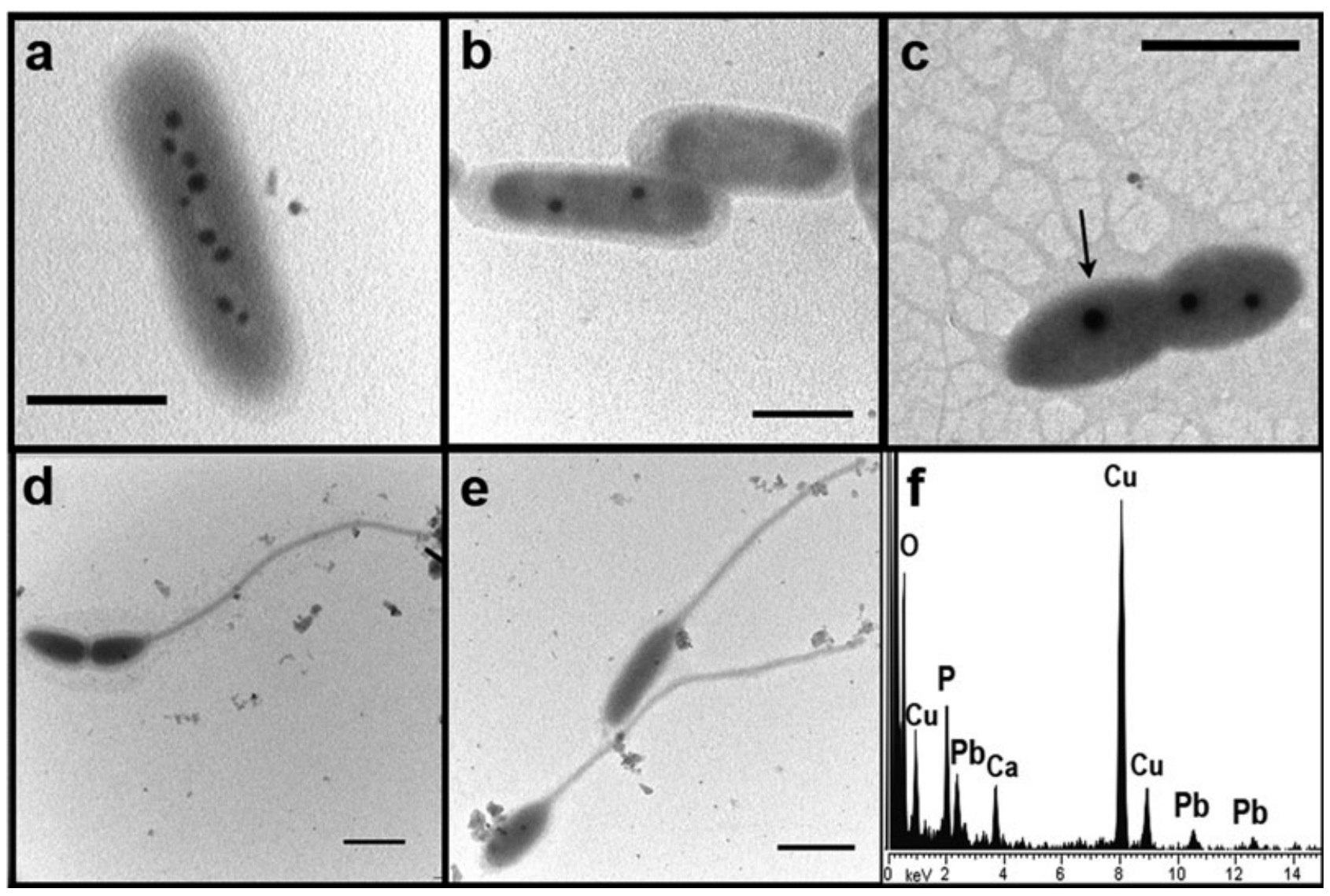

Figure 4 Selected TEM microphotographs of bacteria sampled in the soil water at three different depths over the 8-month monitoring period. (a,b) Coccobacillus-shape bacteria with internal granules (c) Coccobacillus-shape bacteria with internal granules and exopolymeric substance. (d,e) Bacillusshape bacteria with polar flagellum. (e) EDX micro-analysis of the granule indicated by arrow in c. Amount of $\mathrm{P}$ is $5.98 \mathrm{wt} . \% \mathrm{P}_{\text {tot }}$, amount of $\mathrm{Pb}$ is 7.68 wt.\% $\mathrm{Pb}_{2} \mathrm{O}_{5}$. Quantifications are semi-quantitative and not corrected for $\mathrm{C}$ values resulting from the grid coating. The $\mathrm{Cu}$ peak derives from the grid. Scale bar: $1 \mu \mathrm{m}$. (After Perdrial et al., 2008b.) 
typical SOM particles are shown in Figure 5. Those particles were freely suspended in solution, occurring as biological veils or lacings (Figure 5a-d) comprising, for example, dead cells, humic acids, vegetal mucus, disconnected EPS and disconnected bacterial secretions. Chemical analysis showed that SOM was very similar to bacteria and composed of $\mathrm{C}, \mathrm{H}, \mathrm{N}, \mathrm{O}, \mathrm{P}, \mathrm{S}$ and $\mathrm{Cl}$; additionally, most of the particles contained traces of various metals such as $\mathrm{Fe}$, $\mathrm{As}, \mathrm{Pb}, \mathrm{Zn}$, Ni or $\mathrm{Cd}$. The particle size was generally very small, with approximately $95 \%$ of the 2524 measured SOM particles having diameter $<0.45 \mu \mathrm{m}$ (Figure $5 \mathrm{e}$ ). This combination of small size and heterogeneity in shape leads to very large surface areas and thus results in a very high reactivity.

\section{Organo-mineral nanoaggregates}

The fourth main type of particle sampled in the soil infiltration water was represented by organo-mineral nanoaggregates. Nanoaggregates were seen to always have a biological phase as a matrix, mainly bacteria and associated SOM as shown in Figure 6. The sizes and shapes of such components were heterogeneous in nature and no clear trend was visible in particle size distribution.

Figure 6(a) shows a nanoaggregate composed of three bacteria (light grey, bacillus-shaped), three clay particles (darker platelets) and other small particles as oxides (very dark nanospheres) that are all surrounded by flakes of SOM (very light grey veils). The surface area of this aggregate was $2.5 \mu \mathrm{m}^{2}$. Similarly, the nanoaggregate presented in Figure 6(b) was composed of two bacteria and two clay particles, included in a matrix of SOM that is enriched in $\mathrm{Pb}$. The total surface area of this nanoaggregate was $4 \mu^{2}$.

Usually 'microaggregate' includes all aggregates $<250 \mu \mathrm{m}$, with various other smaller size limits, for example $53 \mu \mathrm{m}$ (Six et al., 2000) and $20 \mu \mathrm{m}$ (Lehmann et al., 2007). In our study, we define as nanoaggregates the heteroaggregates that have a size $<5 \mu \mathrm{m}$ in diameter and are composed of a mixture of different particles with sizes in the nanometre to micrometre range.

\section{Particle type distribution in space and time}

Monitoring each type of nanoparticle over 8 months at three different depths enabled us to establish a particle distribution pattern with depth and time. Here the soil hydrodynamic characteristics can be described as a function of the saturation state, the composition of the soil solution, and its energy. Proportions of the different types of particles are given in percentage of covered area.

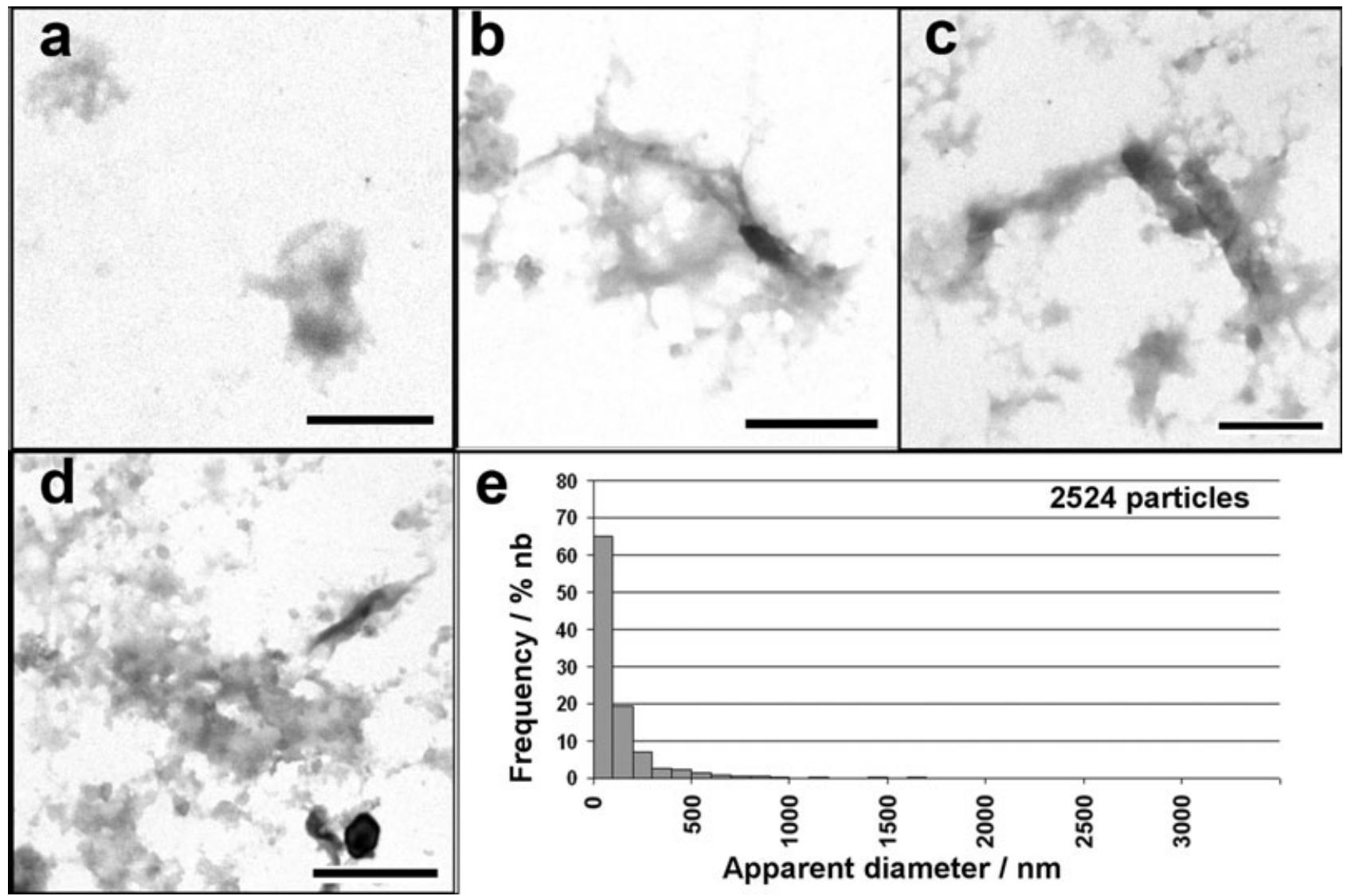

Figure 5 (a-d) Selected TEM microphotographs of soil organic matter (SOM) sampled in the soil water at three different depths over the 8-month monitoring period. (e) Particle size distribution of 2524 SOM particles. \% nb stands for percent of the number of particles. Scale bar: $1 \mu \mathrm{m}$. 


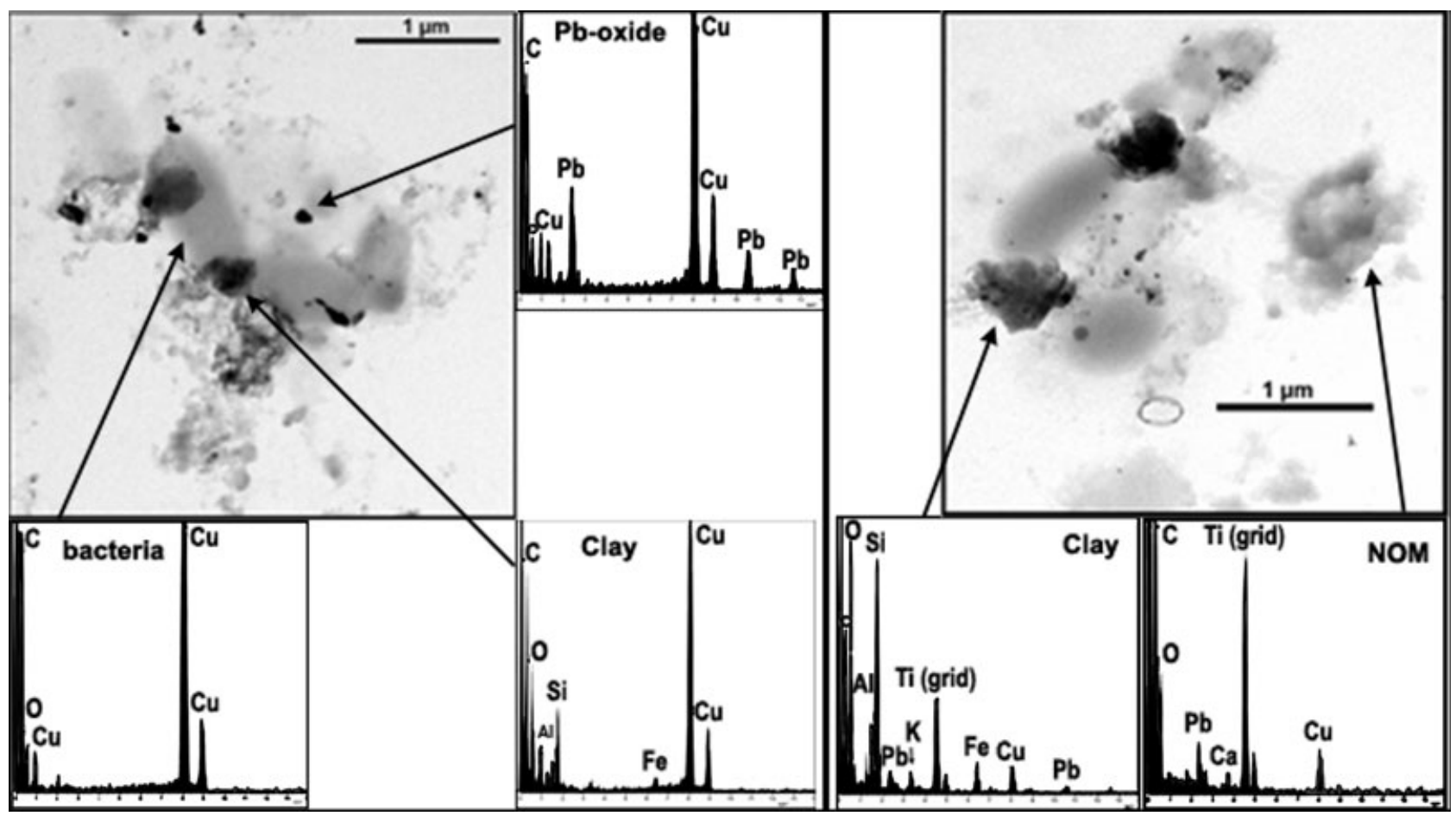

Figure 6 Selected TEM microphotographs of organo-mineral nanoaggregates and corresponding individual particles analyses. (a) Nanoaggregate composed of three bacteria, three clay particles and other small particles, all surrounded by soil organic matter (SOM). Corresponding microanalyses show that all components of the nanoaggregate can be individually characterized. (b) Nanoaggregate composed of two bacteria and two clays, all included in SOM enriched in $\mathrm{Pb}$. Corresponding microanalyses show that all components are slightly enriched in $\mathrm{Pb}$.

Distribution with depth. The cumulative distribution in percentage of covered area for the entire sampling period for each depth $(15,35$ and $55 \mathrm{~cm})$ is given in Figure 7 . A clear change in the main types of particles was visible: the relative amounts of clays decreased with depth, whereas the relative amounts of bacteria and nanoaggregates showed an opposite trend. The relative amounts of salt displayed serve as an indicator for the ionic strength of the soil water, which increased with depth.

Particle distributions are additionally displayed in Figure 8, representing a conceptual model of the relationship between hydrodynamics and soil nanoparticle distribution. Particles sampled at $15 \mathrm{~cm}$ depth were dominated by clay minerals, representing more than $40 \%$ of the entire pool. Bacteria, with a relative amount of $8 \%$, were less abundant in the surface horizon compared with the relative amount observed at greater depth $(12 \%$ at $35 \mathrm{~cm}$ and $21 \%$ at $55 \mathrm{~cm}$ ). This appears to contradict the fact that bacteria were expected to be more abundant in topsoil than in deeper horizons as described by Nunan et al. (2002). However, large densities of microorganisms often form large colonies entrapped in biofilms that are held back by the filters. Aggregates represent relatively small fractions, of only $12 \%$. This may be because the upper surface of the soil was generally unsaturated and the aggregation process was hampered when the pore space contained less moisture. Moreover, rain events led to an enhanced erosion of the pore walls, enhancing the amount of clay particles moving through the pore space relative to the nanoaggregates.

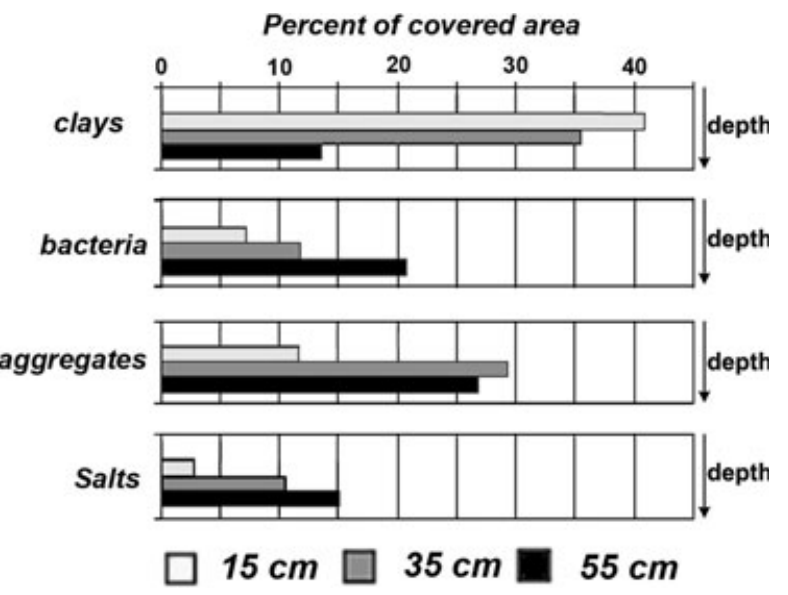

Figure 7 Changes in the distribution of clays, bacteria, aggregates and salts in relation to increasing depth.

At a depth of $35 \mathrm{~cm}$, the relative amount of clay particles decreased whereas aggregates and bacteria became increasingly important. As the pore-space moisture content increased, the aggregation process was facilitated. At the same time, rainwater leached more soil and increased the ionic strength, which facilitated the aggregation. As a result, the amount of individual, non-aggregated clay particles decreased. With increasing depth, 


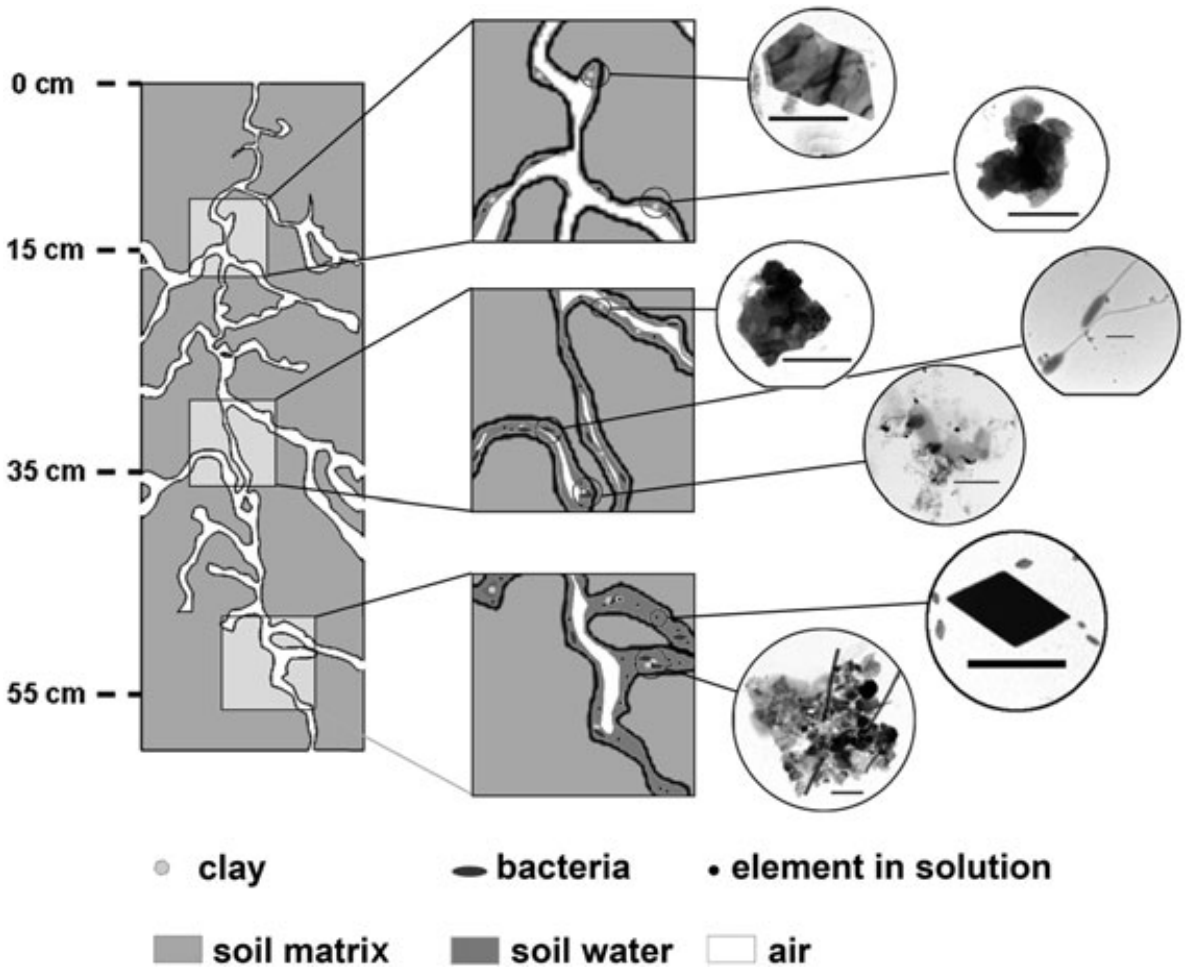

Figure 8 Interpretative diagram of the change in the distribution of particles with depth. Scales of the sketch are not proportional. Scale bars for TEM microphotographs: $1 \mu \mathrm{m}$. the energy of the water flow was reduced and erosion of the soil matrix lessened, thereby reducing the production of individual clay particles. Bacteria, in contrast, were actively growing and their individual relative amount was not affected by the nanoaggregation process. The resulting higher (bulk) amount of bacteria at this depth was in accordance with measurements of bacterial population by Bruneau et al. (2005), who reported no decrease in the cell density between 0 and $32 \mathrm{~cm}$ of a Scottish cambisol.

Finally, at a depth of $55 \mathrm{~cm}$ the main particles found were nanoaggregates $(26 \%)$ and individual bacteria (21\%), and clay particles represented less than $15 \%$ of the total pool. The trend of increasing amounts of salts observed at $35 \mathrm{~cm}$ persisted. We suggest that the same overall processes as in the shallower $35 \mathrm{~cm}$ depth were operative and were likewise triggered by soil moisture. Aggregates were abundant and formed at the expense of individual clay particles, whereas the greater ionic strength facilitated both clay-to-clay and clay-organics aggregation. As divalent cations were enhanced (the primary salts crystallizing on the grids were calcium chlorides) it was likely that the binding of bacteria on clay surfaces was facilitated as well. However, the relatively large amount of bacteria (more than 20\%) suggests that they were essentially present as individual cells forming only few and small colonies as already described by Nunan et al. (2002).

Distribution with time. The change in the sampled particles at all depths is displayed as a function of time in months in Figure 9. For this purpose, particle distribution was simplified and classified into three types: (i) mineral particles (euhedral and weathered anhedral clay particles and oxi-hydroxides), (ii) organic particles (bacteria and SOM) and (iii) aggregates. Abundances were normalized to $100 \%$. Salts were not included in order to avoid the impact of water as an additional factor. The evolution of the amount of mineral particles showed a constant decrease from December, with values ranging between 49 and $85 \%$ (depending on depth), to July where the maximum amount was below $10 \%$ (Figure 9a). The general change in the amount of organic particles showed the opposite trend, with an increase during the same period (Figure 9b). Starting values in December ranged between 8 and $50 \%$, while in July the relative amount of organic particles had increased by up to four times with values ranging between 31 and $66 \%$. The only exceptions in this pattern were the relatively large values for organics in December at $55 \mathrm{~cm}$ and January at 15 and $55 \mathrm{~cm}$, which could reflect a thawing event of the topsoil leading to a sudden increase in SOM production because of the disruption of soil aggregates, as shown by Edwards (1991). However, we do not understand the absence of a SOM pulse in January at $35 \mathrm{~cm}$. The trend for change in the amount of aggregates was similar to that of the organic particles, with increased amounts towards the warmer period of the year (Figure 9c). The largest percentage of aggregate coverage on the sampling grids occurred in December (27\%), whereas in July between 31 and $56 \%$ of the area was covered by nanoaggregates. In contrast to the change in organic particles, the aggregates showed no peak in January and it is likely that SOM production was a short-term event that did not allow the aggregation processes to take place.

The evolution of the distribution of bacteria and SOM and aggregates followed the same general trend, suggesting that they 

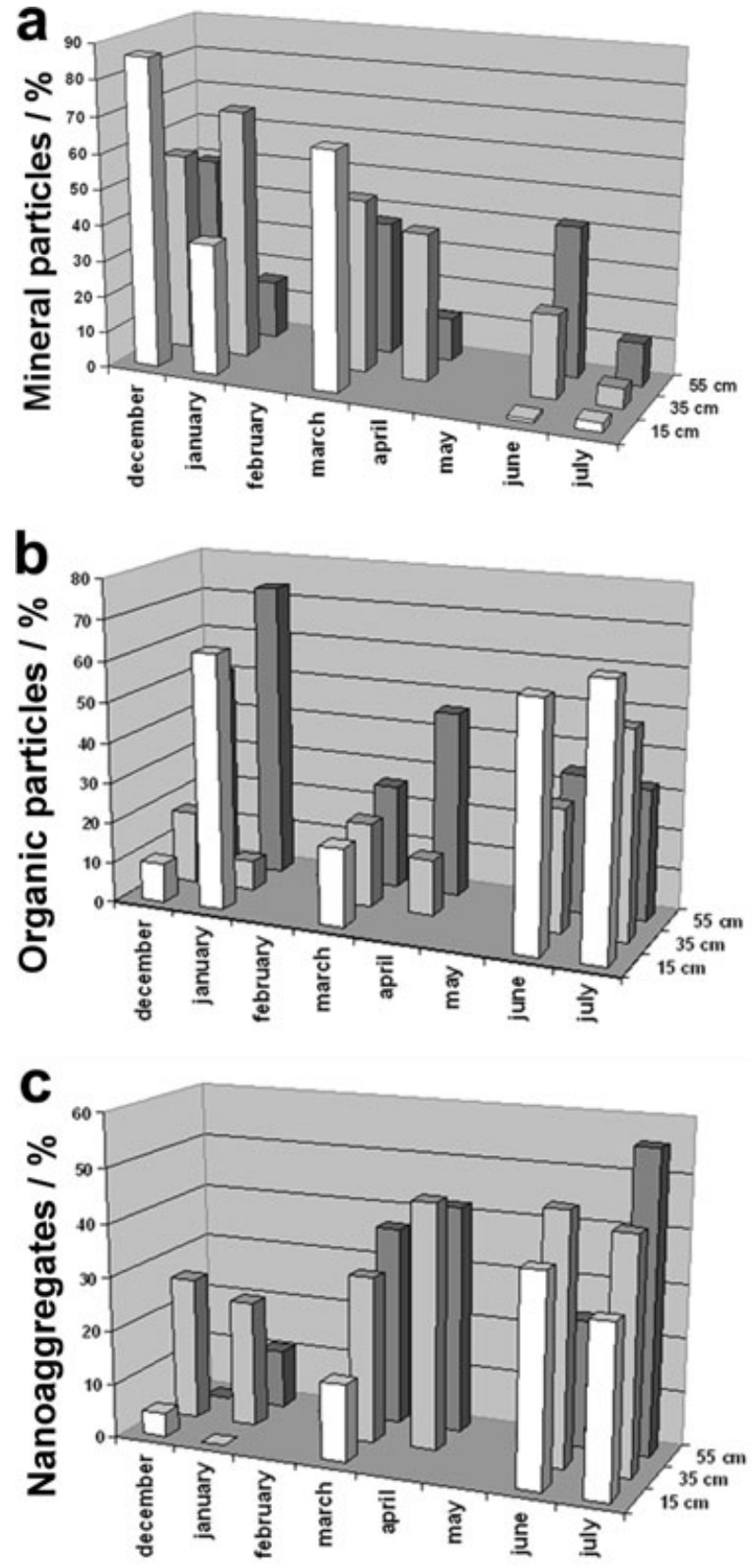

Figure 9 Changes in the distribution of the particles with time at each depth: (a) mineral particles (clay, weathered clay and oxi-hydroxide), (b) organic particles (bacteria and SOM) and (c) aggregates. No data are available for February and May at all depths and April at $15 \mathrm{~cm}$.

are interlinked. As the amounts of bacteria and aggregates tended to increase, the amount of free clay particles decreased because they are incorporated into nanoaggregates and are, unlike the bacteria, not constantly renewed.

The temperature and precipitation recorded during the monitoring period are shown in Figure 10. Both factors showed a general increase from December towards July and this fits the observed

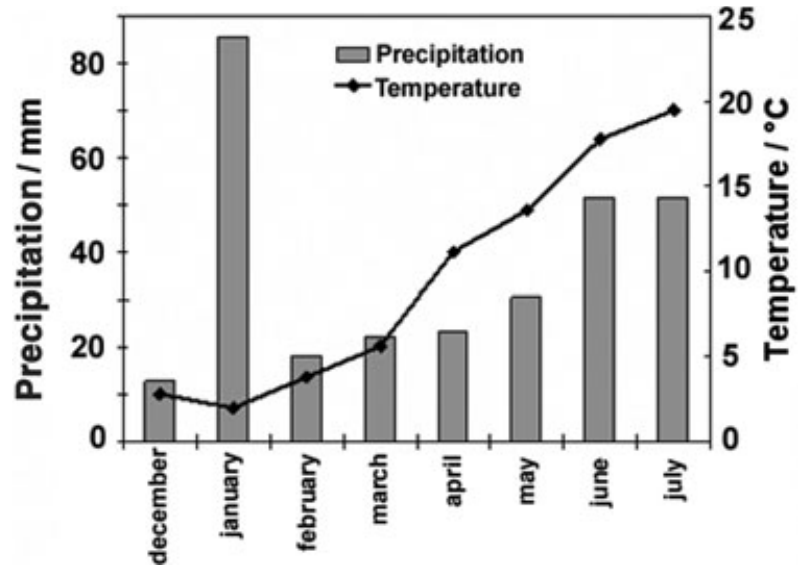

Figure 10 Variation of precipitation and temperature at the experimental site over an 8-month monitoring period.

trends in organic particle and aggregate evolution. In-situ studies on microbial community composition in soil (Zhang et al., 2005; van Meeteren et al., 2008) have shown that the microbial community is dominated by bacteria at warmer temperatures. The in-situ field observations in the present study confirm this correlation as the organic particles were mostly dominated by bacteria. Additionally, our study provides evidence that nanoaggregation was dependent on climatic factors, being enhanced during warm and wet periods (Figure 9c). Superimposed on the above-described long-period trends, is some month-to-month variability, which could not clearly be related to any of the monitored factors.

\section{Implications for metal contaminant transport}

All of the different particles, suspended in the soil solution, exhibit a potential for contaminant metal transport through the soil matrix. Clay particles are well known to adsorb free cations onto their negatively charged surface, particularly metal cations involved in clay facilitated transport (reviewed in Bradl, 2006). In this case, the role of the clay is manifested in its cation exchange capacity and by the small size and corresponding high specific surface area of the particles. Our results show that individual clay particles often show enrichments in various elements, especially metal(loid)s suggestive of organic and metal coatings. In this case, the layered clay particles act as a substrate to transport or store $\mathrm{OM}$ and metals vertically.

Bacteria investigated in our study were often enriched in $\mathrm{Pb}$. This contaminant enrichment has been previously described (Perdrial et al., 2008b) and highlights the potential role of bacteria in contaminant transfer through the soil-pore space. Here, we show that bacterial-facilitated metal transport is potentially an important mechanism in the vadose zone. Additionally, because complexation processes often modify metals from a true dissolved state to a colloidal state (Kretzschmar et al., 1995), the presence of metals in the collected SOM suggests that their bioavailability was decreased and that SOM acts as a vehicle for transport in the soil pore space. 
The implications of the presence of nanoaggregates for the fate of metals in soils result from the mutual reactivity of the different compounds. Numerous examples exist that show that $\mathrm{OM}$ and bacteria have a strong impact on chemistry, toxicity and mobility of metals (Beveridge, 2005). Borrok et al. (2007) investigated a ternary system of bacteria-OM-metals and concluded that such complexes have an impact on the mobility of metal cations in natural systems in a different way to simpler systems. Dissolved OM-metal complexes were transformed to (more reactive) colloidal bacteria-metal-OM complexes.

Our results show the strong association between metals and clay particles. Additionally, the association of clay particles, OM and metals has an enhanced complexation potential that has a strong impact on the mobility of metals. We propose, according to Schroth \& Sposito (1998), that, because (i) clay and OM can form stable associations, (ii) metals can be strongly complexed to $\mathrm{OM}$ and (iii) metals show a high affinity for clays, ternary metal complexes as described by Borrok et al. (2007) can be strongly associated with clay.

Pokrovsky et al. (2005) grouped different elements in peat soil waters according to their affinities to be best associated with either inorganic species (and organic complexes), biologically essential elements or elements associated with $\mathrm{Al}, \mathrm{Fe}$ and organic carbon. Because all assemblages were present in the observed nanoaggregates, the complexation potential of both organic and inorganic components, including contaminant metals, is enormous.

\section{Nucleation model for nanoaggregates as a precursor of microaggregates}

The small size and number of particles that constitute the nanoaggregates were crucial for studying the mechanisms involved in the formation of larger microaggregates. Recently, Lehmann et al. (2007) proposed a conceptual model of free stable microaggregate formation that involved the development of an organic coating on clay minerals followed by the physical occlusion of the organic coating by a second mineral. Architectural observations of our samples permit us to refine and extend this model, particularly with respect to the nucleation stage of aggregation. We hypothesize that surface charge processes are of major importance, especially at the nanoscale, and have to be taken into account for each individual compound.

Our observations of nanoaggregates emphasize the presence of bacteria in close association with minerals. However, both particle types are negatively charged and, because of overlapping of the diffuse double layers, should repel each other. We therefore suggest that the presence of divalent bridging cations, such as $\mathrm{Ca}^{2+}$ or metal cations, is an important aspect in triggering this association and leading to an early two-compound nanoaggregate (Figure 11, step 1-2). Additionally, it can be assumed that bacterially produced surfactants are excreted to prepare the mineral surfaces for adhesion (Bodour \& Maier, 2002).

Such an early-stage nanoaggregate would then be encapsulated in a bacterially produced polymeric substance (Figure 11, step 3).
Such substances are known to be negatively charged (Morgan et al., 1990) and as a result the net assemblage becomes negatively charged. Further binding with other negatively charged clay particles (surrounded by positive counter-ions) would then be facilitated (Figure 11, step 4). The aggregate's outer limits may exhibit predominantly positive charges, which in turn bind with negatively charged microorganisms. If those microorganisms produce negatively-charged polymeric substances, the entire assemblage may be encapsulated (Figure 11, step 5). During this process, the previously aggregated $\mathrm{OM}$ is preserved by the surrounding clay particles but it is probable that the encapsulated bacteria undergo lyses inside the microaggregate (shown on Figure 11, step 5).

This attempt to explain the formation of nanoaggregates is in agreement with the observations of the strong association between clays and microbially produced polymeric substances observed by electron microscopy in various environments (Buffle \& Leppard, 1995; Wilkinson et al., 1997; Chenu \& Plante, 2006; Mikutta et al., 2007). In our experiments, the cations, either sorbed on negatively-charged surfaces or serving as an initial bridge during the aggregation process (Figure $3 \mathrm{c}$ and corresponding discussion), were detectable in the nanoaggregates (Figure 6). The theory that cations trigger early nanoaggregate formation in this soil implies that they become strongly immobilized during aggregate growth. Our study shows that those cations could also be contaminants $(\mathrm{Pb}, \mathrm{Zn}$ and $\mathrm{Cd})$. Additionally, nanoaggregates always involve an important amount of $\mathrm{OM}$ and therefore constitute an important pool of $\mathrm{C}$ in the soil pore space. Consequently, it is crucial to understand the early nanoaggregation processes and identify the compounds involved when studying colloid-facilitated metal contaminant transport and the fate of $\mathrm{C}$ in soils.

\section{Conclusions}

Nanoscale investigations of individual components suspended in a soil pore space revealed the prevalence of four major types of particles: clays, bacteria, SOM and nanoaggregates. Clays often show enhanced values of metals suggestive of the presence of coatings, whereas bacteria showed intracellular accumulation of metals such as $\mathrm{Pb}$. SOM formed complexes with metals such as $\mathrm{Fe}, \mathrm{As}, \mathrm{Pb}, \mathrm{Zn}$, Ni or $\mathrm{Cd}$ and nanoaggregates showed the combined complexation capacity of all other particle types, not only sequestering metals but $\mathrm{C}_{\text {org }}$ as well.

The in-situ monitoring of the distribution of dominant particles and the changes with depth showed a decrease of individual clay particles, coupled with an increase in the amounts of bacteria and aggregates. This suggests that increasing soil humidity with depth facilitates the aggregation process as the increasing ionic strength of the soil solution induces a stronger binding. The in-situ monitoring of the main types of particles in the soil pore space with time shows a positive correlation between climatic factors (precipitation and temperature) and an increase in the amounts of bacteria and nanoaggregates.

Based on nanoscale investigations, a model for nanoaggregate formation as a precursor of existing microaggregate formation 


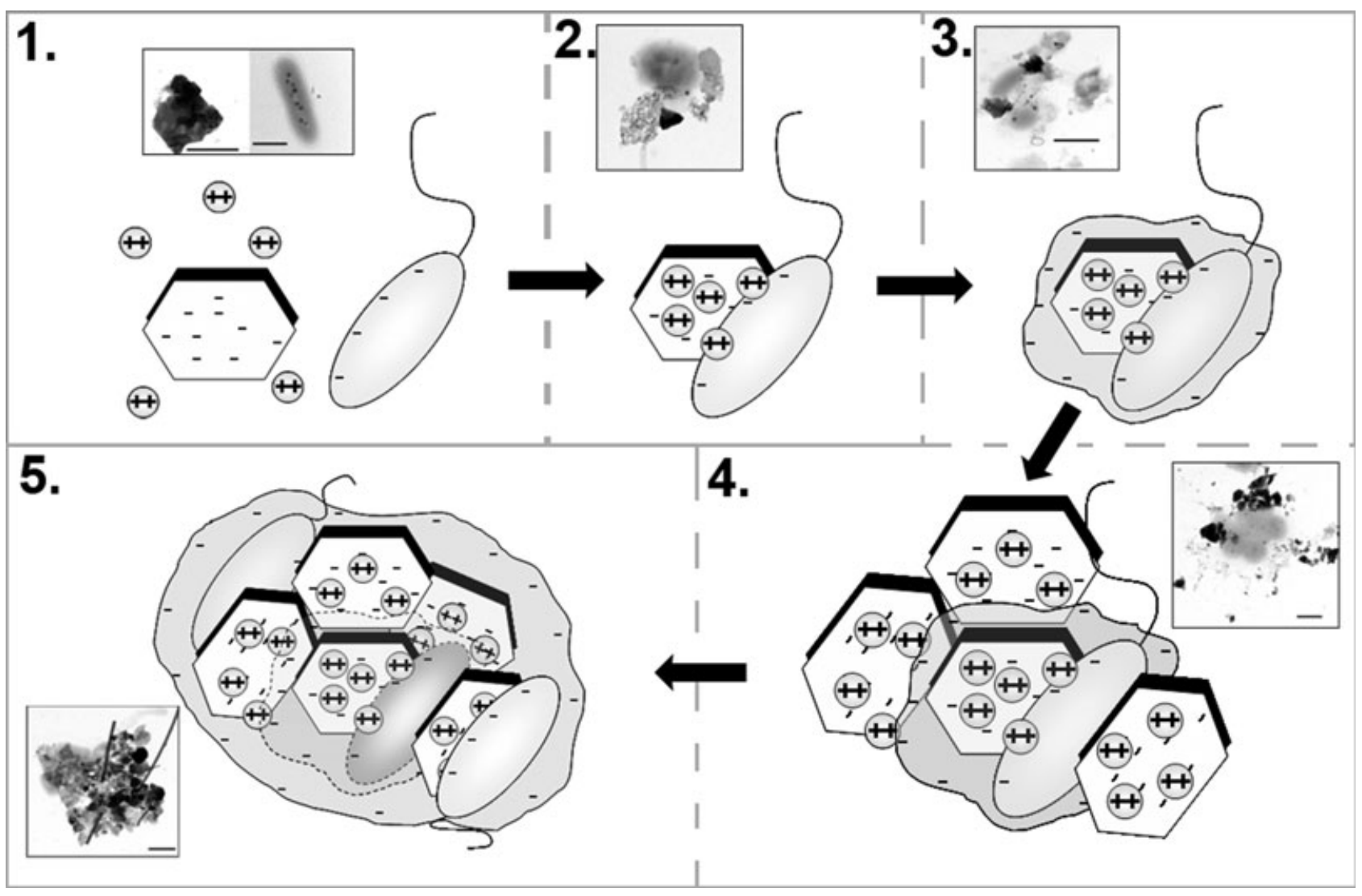

Figure 11 Conceptual representation of the early stages of the formation of nanoaggregates. (1) Negatively charged clay and bacteria in the solution surrounded by free cations. (2) Electrostatic attraction between clay and bacteria through cation bridging. (3) Consolidation of the aggregate by entrapment in extracellular polymeric substance (EPS). (4) Trapping of clays on the EPS through sorption of cations. (5) Production of EPS, consolidating the nanoaggregate. The initial bacterium is lysing in the nucleus of the nanoaggregate and cations sorbed on the surface of clays are entrapped within the nanoaggregate. Steps 2-5 are not necessarily differentiated and can overlap with each other. Scale bar of TEM microphotographs: $1 \mu \mathrm{m}$.

models can be proposed, where successive electrostatic binding and bridging of clay and bacteria by free cations lead to the formation of a nanoaggregate nucleus. During the construction of the aggregate, the $\mathrm{OM}$ previously bound to the mineral is preserved in the centre of the aggregate, the bridging contaminant cations such as $\mathrm{Pb}$ are trapped and soil $\mathrm{C}$ is stabilized.

\section{Acknowledgements}

A PhD fellowship to Nicolas Perdrial by the French Ministry of National Education is thankfully acknowledged. We gratefully thank INRA Colmar for special attention to our work, advice and technical support for field experiments. We gratefully thank Dr Jon Chorover for helpful comments and improvement of the manuscript.

\section{References}

Auboiroux, M., Baillif, P., Touray, J.C. \& Bergaya, F. 1996. Fixation of $\mathrm{Zn}^{2+}$ and $\mathrm{Pb}^{2+}$ by a Ca-montmorillonite in brines and dilute solutions: preliminary results. Applied Clay Science, 11, 117-126.
Baham, J. \& Sposito, G. 1994. Adsorption of dissolved organic carbon extracted from sewage sludge on montmorillonite and kaolinite in the presence of metal ions. Journal of Environmental Quality, 23, $147-153$.

Beveridge, T.J. 2005. Bacterial cell wall structure and implications for interactions with metal ions and minerals. Journal of Nuclear \& Radiochemical Sciences, 6, 7-10.

Bodour, A.A. \& Maier, R.M. 2002. Biosurfactants: types, screening methods, and applications. In: Encyclopedia of Environmental Microbiology (ed. G. Bitton), pp. 750-770. Wiley, Hoboken, NJ.

Borrok, D., Aumend, K. \& Fein, J.B. 2007. Significance of ternary bacteria-metal-natural organic matter complexes determined through experimentation and chemical equilibrium modeling. Chemical Geology, 238, 44-62.

Bradl, H. 2006. Adsorption of heavy metal ions on clays. Encyclopedia of Surface \& Colloid Science, 471, 483.

Bruneau, P.M.C., Davidson, D.A., Grieve, I.C., Young, I.M. \& Nunan, N. 2005. The effects of soil horizons and faunal excrement on bacterial distribution in an upland grassland soil. FEMS Microbiology Ecology, 52, 139-144. 
Buffle, J. \& Leppard, G.G. 1995. Characterization of aquatic colloids and macromolecules. 1. Structure and behavior of colloidal material. Environmental Science \& Technology, 29, 2169-2175.

Chenu, C. \& Plante, A.F. 2006. Clay-sized organo-mineral complexes in a cultivation chronosequence: revisiting the concept of the "primary organo-mineral complex'. European Journal of Soil Science, 57, 596-607.

Chenu, C. \& Stotzky, G. 2002. Interactions between microorganisms and soil particles: an overview. In: Interactions between Soil Particles and Microorganisms (eds P.-M. Huang, J.-M. Bollag \& N. Senesi), pp. 3-40. John Wiley \& Sons, NewYork, NY.

Edwards, L.M. 1991. The effect of alternate freezing and thawing on aggregate stability and aggregate size distribution of some PrinceEdward-Island soils. Journal of Soil Science, 42, 193-204.

Elsass, F. 2006. Transmission electron microscopy. In: Handbook of Clay Science (eds F. Bergaya, B.K.G. Theng \& G. Lagaly), pp. 939-963. Elsevier, Oxford.

Elsass, F., Chenu, C. \& Tessier, D. 2008. Transmission electron microscopy for soil samples: preparation methods and use. In: Methods of Soil Analysis. Part 5. Mineralogical Methods, (eds A.L. Ulery \& L.R. Drees), pp. 235-268 Soil Science Society of America, Inc., Madison, WI, USA.

FAO/ISRIC/ISSS 1998. World Reference Base for Soil Resources. FAO, Rome.

Golchin, A., Oades, J.M., Skjemstad, J.O. \& Clarke, P. 1994. Study of free and occluded particulate organic matter in soils by solid state 13C CP/MAS NMR spectroscopy and scanning electron microscopy. Australian Journal of Soil Research, 32, 285-309.

Gueguen, C. \& Dominik, J. 2003. Partitioning of trace metals between particulate, colloidal and truly dissolved fractions in a polluted river: the Upper Vistula river (Poland). Applied Geochemistry, 18, $457-470$.

Guggenberger, G. \& Kaiser, K. 2003. Dissolved organic matter in soil: challenging the paradigm of sorptive preservation. Geoderma, 113, 293-310.

Hochella, M.F. \& Madden, A.S. 2005. Earth's nano-compartment for toxic metals. Elements, 1, 199-203.

Kaiser, K. \& Guggenberger, G. 2003. Mineral surfaces and soil organic matter. European Journal of Soil Science, 54, 219-236.

Kretzschmar, R. \& Schäfer, T. 2005. Metal retention and transport on colloidal particles in the environment. Elements, 1, 205-210.

Kretzschmar, R., Robarge, W.P. \& Amoozegar, A. 1995. Influence of natural organic-matter on colloid transport through saprolite. Water Resources Research, 31, 435-445.

Lal, R.K.J., Kimble, J.M., Follett, R.F. \& Cole, C.V. 1998. The Potential of U.S. Cropland to Sequester Carbon and Mitigate the Greenhouse Effect. Ann Arbor Press, Chelsea, MI.

Lehmann, J., Kinyangi, J. \& Solomon, D. 2007. Organic matter stabilization in soil microaggregates: implications from spatial heterogeneity of organic carbon contents and carbon forms. Biogeochemistry, 85, $45-57$.

Majzik, A. \& Tombacz, E. 2007. Interaction between humic acid and montmorillonite in the presence of calcium ions I. Interfacial and aqueous phase equilibria: adsorption and complexation. Organic Geochemistry, 38, 1319-1329.

McCarthy, J.F. \& Zachara, J.M. 1989. Subsurface transport of contaminants; mobile colloids in the subsurface environments may alter the transport of contaminants. Environmental Science \& Technology, 23, 496-502.
McCarthy, J.F. \& McKay, L.D. 2004. Colloid transport in the subsurface: past, present and future challenges. Vadose Zone Journal, 3, 326-337.

McDowell-Boyer, L.M., Hunt, J.R. \& Sitar, N. 1986. Particle transport through porous media. Water Resources Research, 22, 1901-1921.

van Meeteren, M.M., Tietema, A., van Loon, E.E. \& Verstraten, J.M. 2008. Microbial dynamics and litter decomposition under a changed climate in a Dutch heathland. Applied Soil Ecology, 38, 119-127.

Mikutta, R., Mikutta, C., Kalbitz, K., Scheel, T., Kaiser, K. \& Jahn, R. 2007. Biodegradation of forest floor organic matter bound to minerals via different binding mechanisms. Geochimica et Cosmochimica Acta, 71, 2569-2590.

Morgan, J.W., Forster, C.F. \& Evison, L. 1990. A comparative study of the nature of biopolymers extracted from anaerobic and activated sludges. Water Research, 24, 743-750.

Nachtegaal, M. \& Sparks, D.L. 2004. Effect of iron coatings on zinc sorption mechanisms at the clay-mineral/water interface. Journal of Colloid and Interface Science, 276, 13-23.

Nunan, N., Wu, K., Young, I.M., Crawford, J.W. \& Ritz, K. 2002. In situ spatial patterns of soil bacterial populations, mapped at multiple scales, in an arable soil. Microbial Ecology, 44, 296-305.

van Oort, F., Jongmans, A.G., Citeau, L., Lamy, I. \& Chevallier, P. 2006. Microscale $\mathrm{Zn}$ and $\mathrm{Pb}$ distribution patterns in subsurface soil horizons: an indication for metal transport dynamics. European Journal of Soil Science, 57, 154-166.

Party, J.-P., Sauter, J., Burtin, M.-L. \& Koller, R. 1999. Guide des Sols d'Alsace: Petite Région Naturelle Plaine Sud-Alsace. Région Alsace, Strasbourg.

Perdrial, N., Elsass, F. \& Liewig, N. 2008a. New technique for in situ sampling of particulate matter and colloids in soil and atmospheric fallout. Colloids \& Surfaces A: Physicochemical \& Engineering Aspects, 317, 742-746.

Perdrial, N., Liewig, N., Delphin, J.-E. \& Elsass, F. 2008b. TEM evidence for intracellular accumulation of lead by bacteria in subsurface environments. Chemical Geology, 253, 196-204.

Pokrovsky, O.S., Dupre, B. \& Schott, J. 2005. Fe-Al-organic colloids control of trace elements in peat soil solutions: results of ultrafiltration and dialysis. Aquatic Geochemistry, 11, 241-278.

Rasband, W.S. 1997-2009. Image J. U.S. National Institutes of Health, Bethesda, MD (At: http://rsb.info.nih.gov/ij/ [accessed on 27 December 2009].

Schlesinger, W.H. 1996. Biogeochemistry: an Analysis of Global Change. Academic Press, San Diego, CA.

Schlesinger, W.H. \& Lichter, J. 2001. Limited carbon storage in soil and litter of experimental forest plots under increased atmospheric $\mathrm{CO}_{2}$. Nature, 411, 466-469.

Schroth, B.K. \& Sposito, G. 1998. Effect of landfill leachate organic acids on trace metal adsorption by kaolinite. Environmental Science \& Technology, 32, 1404-1408.

Sen, T.K. \& Khilar, K.C. 2006. Review on subsurface colloids and colloid-associated contaminant transport in saturated porous media. Advances in Colloid \& Interface Science, 119, 71-96.

Six, J., Elliott, E.T. \& Paustian, K. 2000. Soil macroaggregate turnover and microaggregate formation: a mechanism for $\mathrm{C}$ sequestration under no-tillage agriculture. Soil Biology \& Biochemistry, 32, 2099-2103.

Six, J., Conant, R.T., Paul, E.A. \& Paustian, K. 2002. Stabilization mechanisms of soil organic matter: implications for C-saturation of soils. Plant \& Soil, 241, 155-176. 
Sparks, D.L. 2005. Toxic metals in the environment: the role of surfaces. Elements, 1, 193-197.

Srodon, J., Morgan, D.J., Eslinger, E.V., Eberl, D.D. \& Karlinger, M.R. 1986. Chemistry of illite/smectite and end-member illite. Clays \& Clay Minerals, 34, 368-378.

Tisdall, J.M. \& Oades, J.M. 1982. Organic matter and water-stable aggregates in soils. Journal of Soil Science, 33, 141-163.
Wilkinson, K.J., Joz-Roland, A. \& Buffle, J. 1997. Different roles of pedogenic fulvic acids and aquagenic biopolymers on colloid aggregation and stability in freshwaters. Limnology \& Oceanography, 42, 1714-1724.

Zhang, W., Parker, K.M., Luo, Y., Wan, S., Wallace, L.L. \& Hu, S. 2005. Soil microbial responses to experimental warming and clipping in a tallgrass prairie. Global Change Biology, 11, 266-277. 